\title{
Krisis Epistemologis Pesantren dalam Kajian Pluralisme Agama
}

\author{
*M. Fachrurrozi, Siti Nur Ami'in \\ Institut Pesantren Mathali'ul Falah Pati \\ *Email korespondensi: el rozie@gmail.com
}

\begin{abstract}
The diversity of understanding among pesantren about religious pluralism is an ambiguity. This situation reflects an epistemological crisis in the search for the meaning of religious truth. This paper tries to explain the epistemological crisis of pesantren in studying religious pluralism. The data in this study include linguistic symbols in the form of prominent concepts and are often used in discourses on religious pluralism, especially those that cover the reasoning of pesantren through their characters as outlined in a number of works. This method of effort produced results in the form of an explanation of the similarity in fundamental values of religions centered on the existence of a witness equation: la ilahb illa Huwa. The various views on religious pluralism are a reflection of the differences in responding to the relationship between single truth and the factual dimension of the plural itself. Among pesantren pluralists, there is no sharp difference in the existence of truth in each religion.
\end{abstract}

Keywords: religious pluralism, systematic-reflection, the epistemological crisis of pesantren

\begin{abstract}
Abstrak
Keanekaragaman pemahaman di kalangan pesantren tentang pluralisme agama merupakan suatu ambiguitas. Situasi ini mencerminkan adanya krisis epistemologis dalam pencarian makna kebenaran agama. Tulisan ini mencoba menjelaskan krisis epistemologis pesantren dalam mengkaji pluralisme agama. Data dalam penelitian ini meliputi simbol-simbol kebahasaan yang berupa konsep-konsep yang menonjol dan sering digunakan dalam diskursus tentang pluralisme agama, terutama yang menyelubungi nalar pesantren melalui tokohnya yang dituangkan dalam sejumlah karya. Metode Usaha ini membuabkan hasil yang berupa penjelasan tentang adanya persamaan nilai fundamental agama-agama yang berpusat pada adanya persamaan persaksian: là iläh illa Huwa. Ragam pandangan tentang pluralisme agama merupakan cermin dari adanya perbedaan dalam menanggapi relasi antara kebenaran tunggal dan dimensi faktual tentang yang plural itu sendiri. Di kalangan pluralis pesantren tidak ditemukan perbedaan yang tajam menyangkut adanya kebenaran pada setiap agama.
\end{abstract}

Kata kunci: pluralisme agama, refleksi-sistematis, krisis epistemologis.

\section{A. Pendahuluan}

Ramainya perdebatan mengenai pluralisme agama sampai dengan hari ini senantiasa diwarnai oleh munculnya dua kubu yang bertentangan: mendukung dan menolak. Fakta ini bertolak dari pemahaman yang berbeda dan beraneka dalam menanggapi realitas tentang kebenaran tunggal yang bersifat absolut. Para 
pendukung pluralisme agama (pluralis) meyakini bahwa kebenaran tersebut tidak boleh dimonopoli oleh suatu agama. Bahwa setiap agama memiliki hak yang sama untuk membuat klaim kebenaran atas ajaran agamanya sendiri sebagai yang absolut. Sedangkan penolakan oleh para pengritiknya (partikularis) didasari oleh keyakinan bahwa hak atas klaim tersebut hanya terdapat pada atau dimiliki oleh agamanya sendiri.

Sesuatu hal yang cukup menonjol di kalangan partikularis adalah pandangan yang cenderung seragam yang menampil secara simplistis sebagai gugatan atas gagasan bahwa semua agama adalah sama. Ini disebabkan oleh fokus perhatiannya yang lebih mencurah pada sikap reaktif yang mengemuka dalam bentuk penolakan dan kritik terhadap gagasan yang dianggap sebagai rivalnya itu. Suatu cara pandang dan sikap keagamaan yang dalam kaca mata pluralis dikatakan sebagai eksklusif. ${ }^{1}$ Itu berarti pula bahwa bagi partikularis mencari-cari terlebih lagi mengakui kebenaran tunggal yang terdapat pada agama selain agamanya adalah tidak relevan, bahkan merupakan usaha yang tidak sejalan dengan visi keimanan mereka. Sesuatu hal yang justru dengan sangat serius dikembangkan oleh pluralis.

Fenomena tersebut dijumpai pula dalam tradisi pemikiran atau nalar pesantren yang tercermin dalam pemikiran figur-figurnya yang dianggap penting dan sentral. Di kalangan pluralis untuk saat sekarang ini dapat disebut figur-figur, untuk menyebut beberapa nama, seperti Amin Abdullah, Ulil Absar Abdalla, Komaruddin Hidayat, Budhy Munawar-Rachman, Abdul Moqsith Ghazali dan Zuhairi Misrawi. Sementara itu di pihak partikularis terdapat nama-nama seperti Anis Malik Thoha, Hamid Fahmi Zarkasyi dan Adib Fuadi Nuriz. Selain mereka ini tentu saja masih ada banyak nama yang gagasan-gagasannya telah mewarnai nalar pesantren pada masa sekarang ini.

${ }^{1}$ Salah satunya dapat dilihat dari sumber evaluatif yang oleh D'Adamo disebut sebagai Religion's Way of Knowing. Bahwa teks-teks keagamaan: pertama, bersifat konsisten dan penuh dengan klaim kebenaran; kedua, bersifat lengkap dan final; ketiga, teks-teks itu dianggap satu-satunya jalan keselamatan; dan yang terakhir, dalam bahasa asli D'Adamo: have an inspired or divine author (God who is their true Author). Lihat Budhy Munawar-Rachman, "Kata Pengantar", dalam Komaruddin Hidayat dan Muhammad Wahyuni Nafis, Agama Masa Depan Perspektif Filsafat Perennial, Jakarta: Penerbit Paramadina, 1995, h.xxiv. 
Ilman Nafi'a mengurai pemikiran beberapa tokoh Islam dari kalangan pesantren dan akademisi (Perguruan Tinggi Islam di Cirebon). Nafi‘a menemukan dua kecenderungan: pertama, pluralisme dan pluralitas agama adalah dua hal yang berbeda. Pluralitas agama adalah masalah kemajemukan agama dan dianggap sebagai realitas. Sedangkan pluralisme agama dianggap sebagai pencampuradukan dan mempersamakan semua agama, sebagai gagasan yang bermasalah dan dianggap bertentangan dengan ajaran Islam. Kedua, pandangan yang menganggap pluralisme dan pluralitas agama dipahami dalam pengertian yang sama, yakni pengakuan atas kemajemukan atau keragaman agama. Tidak ada masalah dengan pluralisme agama karena sifatnya yang niscaya. Perbedaan pandangan ini pada gilirannya berpengaruh pada bentuk pensikapan atas kedudukan fatwa MUI. Kyai-kyai sepuh dan kyai-kyai yang memiliki hubungan struktural dengan MUI berpendapat bahwa fatwa bersifat mengikat atas umat Islam di Indonesia, sementara kyai-kyai muda dan akademisi berpendapat sebaliknya atau tidak mengikat. ${ }^{2}$

Dari paparan di atas segera diketahui terdapat aspek persamaan -di antara pluralis dan partikularis- dalam memahami pluralitas agama sebagai suatu fenomena yang tidak perlu dipersoalkan dan karenanya diakui keberadaannya. Bagi kedua belah pihak pluralitas agama merupakan suatu kebenaran historis yang bersifat niscaya adanya. Apa yang disebut "niscaya adanya", dalam kaitannya dengan Qs.11:118, ialah apa yang oleh Thoha disebut sebagai kehendak Allah. ${ }^{3}$ Apabila dilihat dari sisi pluralitas sebagai konsep yang dibedakan dari pluralisme maka, dengan pendasaran pada satu ayat yang sama, hal ini seiring dengan penjelasan Moqsith bahwa -sebagai implikasi dari pluralitas maka- pluralisme

2 Ilman Nafi'a, "Fatwa Pluralisme dan Pluralitas Agama MUI (Majlis Ulama Indonesia) dalam Perspektif Tokoh Islam Cirebon," Holistik, Vol.14, Number 01, Tahun 2013, h.148.

${ }^{3}$ Harda Armayanto, "Problem Pluralisme Agama," Jurnal Tsaqafah, Vol. 10, No. 2, November 2014, h.337 -sebagaimana dikutipnya dari Anis Malik Thoha, Tren Pluralisme Agama, Jakarta: Perspektif, 2005, h.28-29. 
adalah sebuah keniscayaan pula. ${ }^{4}$ Pada titik ini muncul persoalan: konsepsi yang manakah yang hendak dijelaskan oleh Qs.11:118, pluralisme ataukah pluralitas?5

Pada pihak yang lain, Zainal Arifin dan Yu'timaalahu Yatazaka menjelaskan terdapat dua bentuk respon dari kedua lembaga terhadap pluralisme agama, yakni sebagai persoalan teologis di satu sisi dan sosiologis di sisi lain. Secara teologis tidak ditemukan adanya perbedaan, keduanya menolak konsep akidah dari orang yang berbeda dengan akidahnya dan cenderung tertutup (truth claim) terhadap keyakinan agama lain. Tidak ada titik temu yang bersifat esoteris-transendental. Tetapi secara sosiologis keduanya menunjukkan sikap atau pengakuan yang sama terhadap fenomena pluralitas akidah dan membiarkan akidah yang lain sepanjang akidahnya tidak terusik. Karena itu keduanya cenderung bersikap inklusif, toleran, humanis, akomodatif dan kooperatif terhadap adanya pluralitas umat beragama. ${ }^{6}$

Adanya simultansi dua pendekatan (teologis dan sosiologis) dalam memberi respon terhadap persoalan pluralisme agama yang semacam itu memperlihatkan cara pensikapan yang bercorak standar ganda -dalam psikologi dikenal sebagai double bind (ikatan ganda), adalah salah satu bentuk distorsi kognitif. Dengan begitu cara pensikapan yang demikian dapat dikatakan sebagai ekslusivismeteologis di satu sisi dan inklusivisme-sosiologis di sisi lain. Dari pemahaman ini lalu berkembang logika: pluralitas yes, pluralisme no! Tidak sedikit yang mengamini logika yang mengandung kerancuan (fallacy) ini. Mana mungkin mensikapi pluralitas tanpa memiliki sandaran pada salah satu perspektif pluralisme. $^{7}$

${ }^{4}$ Lihat Abdul Moqsith Ghazali, Argumen Pluralisme Agama, Depok: Kata Kita, 2009, h.xvi.

${ }^{5}$ Abdurrahman Wahid (Gus Dur) dan Nurcholis Madjid (Cak Nur) adalah dua figur terdepan di garis pemikiran pluralisme agama sampai dengan masa persimpangan milenium kedua dan ketiga. Relasi keduanya bisa diibaratkan dengan relasi antara langit dan bumi, di satu sisi lebih merepresentasikan gagasan mengenai idealitas kehidupan keagamaan yang universal, dan di sisi lain bagaimana idealitas itu ditebarkan di muka bumi dalam perwujudannya yang multikutural. Keduanya bermuara pada gagasan dasar yang sama: mendorong terwujudnya kerjasama agama-agama. Pertanyaan tersebut diinspirasi dari Muslim Abdurrahman, Islam Transformatif, Jakarta: Pustaka Firdaus, 1997, h.81-99.

${ }^{6}$ Zainal Arifin dan Yu'timaalahuyatazaka, "Persepsi Santri Dan Kiai Terhadap Pluralisme Agama Di Pendidikan Ulama Tarjih Muhammadiyah (Putm) dan Aswaja Nusantara Yogyakarta," AlTahrir: Jurnal Pemikiran Islam, Vol. 17, No. 1 Mei 2017, h.201.

${ }^{7}$ Syamsul Arifin, "Konstruksi Wacana Pluralisme Agama di Indonesia," Humanity, Volume V, Nomor 1, September 2009, h.82. 
Sementara itu Komaruddin Hidayat menjelaskan bahwa substansi (inti ajaran) agama bersifat transenden tetapi sekaligus imanen. Ia transenden karena substansi agama sulit didefinisikan dan tidak terjangkau kecuali melalui prediketnya, tetapi sekaligus imanen karena hubungan antara prediket dan substansi tidak mungkin terpisahkan. Kalau saja substansi agama bisa dibuat hirarki maka substansi agama yang paling primordial hanyalah satu. ${ }^{8}$ Oleh karenanya jika pendekatan standar ganda tersebut dicermati melalui jalan pikir ini maka hal itu menunjukkan adanya "keterpisahan" antara yang-transenden dan yang-imanen. Ini berarti tidak ada "kesekaligusan" atau "keserentakan" pada dimensinya yang substantif dari agama-yang-dipikirkan Komaruddin. Jika demikian pertanyaan yang muncul: dapatkah dibuat kemungkinan sebaliknya semisal dengan mengubah standar ganda menjadi standar tunggal, yang berarti bila bukan salah satunya maka- eksklusif sekaligus inklusif, teologis sekaligus sosiologis, atau menerima sekaligus menolak akidah agama lain dalam waktu yang bersamaan? (Atau) bagaimanakah penjelasan, seperti yang dikutipnya dari Seyyed Hossein Nasr, tentang apa yang disebut relatively-absolute, esoteris-eksoteris atau sebaliknya dapat dideskripsi secara lebih benderang?

Apa yang hendak dinyatakan melalui pertanyaan-pertanyaan tersebut di atas bahwa perbicangan tentang pluralisme agama telah menimbulkan perbedaan dan keragaman nalar keagamaan pada tatarannya yang teologis. Pada gilirannya yang begini ini berimplikasi pada munculnya keragaman dalam pemahaman tentang pluralisme agama itu sendiri, dan hal ini dapat diperpanjang lagi daftarnya. Selain diidentifikasi secara simplistis bahwa pluralisme agama merupakan masalah teologis ${ }^{9}$ atau realitas, ${ }^{10}$ kendati masih dalam garis yang sama (teologis-sosiologis), ada pula yang lebih jauh mengancang pluralisme agama sebagai kelanjutan dari -

${ }^{8}$ Komaruddin Hidayat dan Muhammad Wahyuni Nafis, Agama Masa Depan, h.53-54.

9 Budhy Munawar Rachman, Islam Pluralis Wacana Kesetaraan Kaum Beriman, Jakarta: Raja Grafindo Persada, 2004, h.40.

10 Zuhairi Misrawi, Al-Qur'an Kitab Toleransi: Inklusivisme, Pluralisme, dan Multikulturalisme, Jakarta: Fitrah, 2007, h.205. 
dan karenanya memperoleh pendasarannya secara kumulatif pada- relativisme dan dekonstruksionisme. ${ }^{11}$

Sebagian lain menggelutinya melalui wacana tentang dimensi absolutitas pluralisme agama dengan mengkonstruksi ulang nilai-nilai dasar toleransi, ${ }^{12}$ bahkan ada yang melihat pluralisme agama adalah toleransi itu sendiri. ${ }^{13} \mathrm{Di}$ tempat yang lainnya ada pula yang membacanya sebagai justifikasi teologis sebagai pemaksaan konseptual yang sebenarnya tidak dikenal dalam tradisi Islam. ${ }^{14}$

Abdul Wahid Zaini, salah seorang pengasuh pesantren di PP Nurul Jadid Paiton Probolinggo Jawa Timur, pernah menyatakan kegelisahan epistemiknya:

Wacana fiqh yang berkembang di pondok pesantren sungguh telah mengalami reduksi yang sangat drastis, apalagi kalau dikembalikan ke masa Nabi. Reduksi tersebut lebih-lebih dijustifikasi dengan hadirnya pembatasan pada kitab-kitab yang boleh dibaca karena kualifikasinya memenuhi syarat (mu'tabarah) yang sampai saat ini belum jelas rujukan kriteria ataupun sumber munculnya pembatasan tersebut. Model dan tradisi yang berkembang ini tentunya membiasakan kalangan pesantren untuk terfokus pada pemahaman teks dan pengembangan teks fiqh dalam kitab-kitab kuning. Sedangkan bagaimana aplikasi pemahaman tersebut dalam realitas empirik, dan keutuhan perspektif permasalahan dari sudut selain fiqh tentunya menjadi permasalahan sendiri yang selama ini belum mendapat perhatian."15

Ungkapan “...keutuhan perspektif permasalahan dari sudut selain fiqh" dalam pernyataan di atas memberitahu secara tidak langsung adanya krisis epistemologis. Konfirmatif dengan penjelasan Martin van Bruinessen bahwa hingga akhir abad ke-19 dan awal abad ke-20 kajian tafsir masih belum dianggap sebagai bagian sangat penting di pesantren. Kemudian R.M. Feener menyatakan hal serupa bahwa tafsir masih belum menjadi disiplin ilmu yang utama di

11 Amin Abdullah, "Dialog Peradaban Menghadapi Era-Postmodernisme, Sebuah Tinjauan Filosofis-Religius," dalam al-Jami‘ah, Jurnal Ilmu Pengetahuan Agama Islam, IAIN Sunan Kalijaga, No.53 Tahun 1993, h.111-119.

12 Budhy Munawar Rachman, "Perspektif Global Islam dan Pluralisme," dalam Jurnal Ushuluddin, Vol.1 No.3, Januari 2012, 217.

13 Alwi Shihab, Islam Inklusif: Menuju Sikap Terbuka dalam Beragama, Bandung: Penerbit Mizan, 1999, h.41-43.

${ }^{14}$ Hamid Fahmi Zarkasyi, Majalah Gontor, 5 September 2005, h.3-16, dikutip dari Ahmad Khoirul Fata dan Fauzan, "Kritik "INSISTS" terhadap Gagasan Pluralisme Agama," Kalam, Volume 11, Nomor 1, Juni 2017, h.45.

${ }^{15}$ Lihat Baddrut Tamam, Pesantren, Nalar dan Tradisi, Geliat Santri Mnghadapi ISIS, Terorisme dan Transnasionalisme Islam, Yogyakarta: Pustaka Pelajar, 2015, h.88-89. 
pesantren. Kini hal seirama ditegaskan kembali oleh Rosihon Anwar dalam Kajian Kitab Tafsir dalam Jaringan Pesantren Di Jawa Barat, bahwa kajian tafsir di pesantren masih dinomorduakan.

Sebagai inti ajaran yang paling dijaga ortodoksinya tafsir hanya diminati oleh pesantren-pesantren yang memiliki kaitan dengan perguruan tinggi. Baik itu karena santrinya adalah para mahasiswa (pesantren al-Jawami dan al-Wafa), atau karena kyainya pernah belajar di perguruan tinggi (pesantren Buntet), atau karena pesantren itu memiliki perguruan tinggi sendiri (pesantren Darusalam, Cipasung dan al-Mashturiyah). Di pesantren-pesantren inipun kajian tafsir tidak menjadi perhatian yang utama. ${ }^{16}$

Berdasarkan uraian di atas dapat dinyatakan bahwa bila dikaitkan dengan masalah perbedaan dan keragaman dalam pemahaman (ambiguitas) mengenai pluralisme agama maka situasi yang begitu itu memberitahu bahwa krisis epistemologis tengah menggejala di kedalaman nalar pesantren. Situasi ini bertambah problematis terutama apabila dihadapkan pada dimensi-dimensi tekstual seperti "wa allażina yu'minūna bi mā unzila ilaikea wa mà unzila min qablike..." (Qs.2:4), atau "nazzala 'alaik al-kitāb bi al-haqq mușaddiqan limā baina yadaih wa anzala al-taurāt wa al-injill” (Qs.3:3). Disamping itu dijumpai pula ungkapan semisal "al-kitab là raiba fīb" (Qs.2:2), "al-kitāb al-mubìn" (Qs.12:1, 26:2, 28:2, dan 43:2) atau “al-haqq al-mubin” (QS.24:25 dan 27:79).

Secara epistemik hal yang demikian ini selaiknya memperoleh perhatian lebih besar terhadap kemungkinan untuk mengurai akar-akar ontologis dalam nalar pesantren bahkan hingga ke tataran evidensinya semisal pada al-haqq atau $l \bar{a}$ raiba fỉh, yang adalah urat nadi dan jantung epistemologi. ${ }^{17}$

16 Rosihon Anwar, Dadang Darmawan dan Cucu Setiawan, "Kajian Kitab Tafsir dalam Jaringan Pesantren Di Jawa Barat", Wawasan: Jurnal Imiah Agama dan Sosial Budaya, Vol.1, No.1, Januari 2016, h.63.

${ }^{17}$ Evidensi dipahami sebagai "cara bagaimana kenyataan hadir", atau "perwujudan dari ada bagi akal". Secara spesififk berarti "cara bagaimana ada hadir bagi saya". Konsep ini berkenaan dengan konsep tentang kepastian sebagai persetujuan akal yang dijamin oleh evidensi yang memadai. P. Hardono Hadi, Epistemologi, Filsafat Pengetahuan, Yogyakarta: Penerbit Kanisius, 1994, h.104-105. Masalah epistemik ini memiliki kaitan erat dengan dimensi ontologisnya karena apa yang disebut sebagai "mengetahui" tidak lain adalah "meng-ada". Mehdi Ha'iri Yazdi, Ilmu Hudhuri, Prinsip-prinsip Epistemologi dalam Filsafat Islam, Bandung: Penerbit Mizan, 1994, h.17. 


\section{B. Metode Penelitian}

Refleksi sistematis adalah pendekatan yang telah mengakar kuat dalam tradisi filsafat pengetahuan, dan pendekatan inilah yang digunakan dalam penelitian ini. Istilah refleksi sistematis itu sendiri mengacu pada watak dasar dari filsafat itu sendiri: kegiatan refleksi. ${ }^{18}$ Penelitian filsafat pada dasarnya berpijak pada gaya inventif guna mencari pemahaman baru dan lebih menekankan evaluasi

18 Adalah satu dari enam metode dan model penelitian filsafat yang dirumuskan Bekker dan Zubair. Metode-model lainnya: 1) Penelitian Historis-Faktual mengenai a. Tokoh, b. Naskah atau Buku, dan c. Teks Naskah. 2) Penelitian mengenai Suatu Konsep Sepanjang Sejarah. 3) Penelitian Komparatif. 4) Penelitian Pandangan Filosofis di Lapangan. 5) a. Penelitian mengenai Masalah Aktual; dan b. Penelitian mengenai Teori Ilmiah. Lengkapnya lihat Anton Bakker dan Achmad Charris Zubair, Metodologi Penelitian Filsafat, Yogyakarta: Penerbit Kanisius, 1994, h.61-120.

Refleksi (Inggris: reflection, Latin: reflectere, melengkung ke belakang) dalam pengertian yang paling umum berarti meditasi yang dalam, yang bersifat memeriksa. Ini bisa berbeda dengan persepsi yang sederhana atau dengan putusan-putusan langsung, yang involunter mengenai suatu objek. Termasuk di sini "refleksi ontologis". Banyak filosof skolastik modern menyatakan refleksi ontologis sebagai kembali-laginya diri sendiri pada objek yang diketahui. Refleksi ontologis selaku metode metafisika dapat dimengerti dalam arti yang lebih tepat dan lebih mendalam, asalkan abstraksi (sebagai objek yang tepat dari metafisika) dari eksisten konkret sekaligus berarti kembalinya ruh pada hakikatnya yang terdalam. Refleksi juga dimengerti sebagai pembalikan (reflexio $=$ menekuk ke belakang) yang merupakan arti refleksi sebenarnya. Karena itu refleksi secara khusus berarti berpalingnya perhatian seseorang 'dari' objek-objek eksternal, yang mendapat perhatian utama dalam soal-soal biasa, 'kepada' kegiatan ruhani sendiri dan kepada cara berada dimana objek-objek ini dimiliki sebagai objek-objek kegiatan ini. Karena itu konsep refleksi berpautan dengan 'konsep kesadaran' (Inggris: conciousness, dari Latin con [dengan] dan scire [tahu]). Namun kesadaran belaka akan tindakan-tindakan sendiri tidak boleh disamakan dengan refleksi. Kesadaran kiranya diartikan sebagai perhatian eksplisit terhadap kegiatan-kegiatan dan subjeknya, yakni ego (Latin: ego [aku, saya], ego berarti "diri individual"). Refleks (reflex) juga diartikan sebagai respon otomatis dan tidak disadari terhadap sesuatu stimulus yang datang; atau respon yang tidak dipelajari dan tidak disadari yang terjadi secara otomatis akibat keberadaan suatu stimulus. Giddens $(1990,1991)$ telah memformulasikan sebuah penjelasan mengenai studi refleksi terhadap kedirian (self) yang di dalamnya identitas individu tidak lagi didasarkan hanya pada faktor-faktor eksternal, akan tetapi dikonstruksikan oleh refleksi terus-menerus pada, dan usaha pembentukan dan pembentukan kembali, biografi mereka. Lihat Lorens Bagus, Kamus Filsafat, h.179 dan 452. Alex Sobur, Kamus Psikologi, Bandung: Pustaka Setia, 2016, h.470. Nicholas Abercrombie, Stephen Hill, Bryan S. Turner, Kamus Sosiologi, Yogyakarta: Pustaka Pelajar, 2010, h.462-463.

Pada ranah etika metode refleksi-sistematis bisa dikaitkan dengan metode yang dikembangkan Joseph Bluter yang membedakan antara dua macam pengalaman batin: antara dorongan-dorongan spontan langsung di satu pihak dan kemampuan untuk merefleksikan dorongan-dorongan itu di pihak lain. Moralitas pada hakikatnya bukan perasaan, melainkan kemampuan untuk berefleksi. Dorongandorongan spontan, termasuk berbagai naluri, keinginan, perasaan dan nafsu, muncul begitu saja dalam diri kita tanpa dikehendaki -selayak insting yang ada pada binatang. Dorongan-dorongan ini buta terhadap penilaian baik dan buruk dalam arti mereka langsung terarah pada sebuah objek tanpa pertimbangan apapun. Moralitas justru tidak termasuk dalam kategori ini, melainkan suatu kemampuan mengadakan penilaian atas dorongan-dorongan itu berdasarkan suara hati. Jadi moralitas merupakan pelaksanaan kemampuan manusia sebagai apa yang disebut bertanggung-jawab. Suara hati bukan emosi melainkan mengatakan apa yang wajib dilakukan. Lihat Franz Magnis Suseno, 13 Tokoh Etika, Yogyakarta: Penerbit Kanisius, 1997, h.109-120. 
pada pengetahuan yang disajikan sebagai data. Dalam penelitian ini data yang dimaksud ialah meliputi simbol-simbol kebahasaan yang berupa konsep-konsep yang menonjol dan sering digunakan dalam diskursus tentang pluralisme agama, terutama yang menyelubungi nalar pesantren via pembicaranya yang berpengaruh, yang dituangkan dalam karya-karya yang tersebar di sejumlah sarana-media. Jadi jenis penelitian ini merupakan penelitian kepustakaan.

Data-data (konseptual) yang telah diinventarisasi lantas diinterpretasi dan dievaluasi berdasarkan unsur-unsur metode yang telah ditetapkan dengan tetap mempertimbangkan hal-hal yang penting seperti konsistensi atau koherensi internal dan holistikanya. ${ }^{19}$ Sebagai kesatuan gagasan unsur-unsur metode dalam pendekatan refleksi-sistematis tersebut merepresentasi cara pembacaan yang didasarkan pada aspek diakronik-sinkronik (ruang-waktu) yang digali dari Surat alNur terutama berkenaan dengan konsep misykāt (Qs.24:35).

Secara metodologis pendekatan tersebut dikonstruksi dari teori tentang sistem signifikasi atau penandaan ( bi 'ilm Allāh, Qs.11:14) yang tersusun dari unsurunsurnya: teori tentang strukturasionalitas teks-konteks ('ilm al-kitäb, Qs.13:43), teori tentang sistem waktu atau relasi ruang-waktu ('ilm al-säah, Qs.41:47, 43:85, 31:34), dan teori refleksi dari realitas tak tampak ('ilm al-ghaib, Qs.53:35). Secara praksis, sebagai pengalaman mental-kesadaran, semuanya itu lantas distrukturasikan ke dalam teori tentang kebenaran-evidensi, sesuatu yang sering disebut al-haqq atau yang-nyata ('ilm al-yaqin, Qs.102:5). ${ }^{20}$

\section{Pembahasan}

\section{Pluralisme Agama dalam Perspektif Pesantren}

Gagasan tentang kesatuan agama-agama, semua agama adalah identik, atau yang seirama dengan itu, sebagai “rumpun atau keluarga Ibrahimi”" segera menemu

${ }^{19}$ Lihat Anton Bakker dan Achmad Charris Zubair, Metodologi Penelitian Filsafat, h.17.

${ }^{20}$ Metode ini barangkali bisa mendorong proyek besar Amin Abdullah: integratif-interkonektif yang berbasis tekstualisme dan rasionalisme, yang menurutnya belum benar-benar tuntas. Saat ini yang harus digarap ulang adalah merekonstruksi teologi, filsafat dan studi agama; bahwa agama itu wahyu Tuhan yang mengatur hubungan manusia dengan Tuhannya, manusia dengan diri sendiri dan lingkungan sosial. Lihat Ahmad Izudin, "Paradigma Integrasi-Interkoneksi: Analisis Epistemologis Pemikiran Keislaman M. Amin Abdullah," dalam Jurnal Islamic Review (J.I.E), Volume IV No.1, April 2015, h.116, 119. 
formulasinya yang baru yang lebih substansial. Hal ini mengindikasi pula (untuk tidak membuat generalisasi), bahwa dalam batas-batas tertentu pandangan kalangan pluralis dianggap lebih memiliki nuansa "kebijaksanaan" ketimbang (juga bukan hendak membuat generalisasi) kalangan partikularis yang cenderung reaktif (relasi antara ofensif dan defensif). Setidaknya kalangan pluralis telah menunjukkan kemampuannya dalam "melihat diri sendiri", dalam artian "melihat agamanya sendiri" sebagai sesuatu yang tidak tabu untuk terus-menerus dipertanyakan, dan karenanya berpeluang untuk bertransformasi ke arah negasidiri (là ilāh) yang bersifat ke-dalam (refleksif).

Ini relevan dengan pandangan Munawar-Rachman bahwa pada dasarnya pokok ajaran pangkal kebenaran universal yang tunggal itu adalah paham Ketuhanan Yang Maha Esa, atau tauhid. Tugas para rasul adalah menyampaikan ajaran tentang tauhid ini, dan ajaran tentang keharusan manusia tunduk dan patuh (mengikat diri) hanya padaNya saja. Dalam pandangan teologi Islam sikap tauhid ini ditafsirkan sebagai suatu harapan kepada semua agama yang ada: bahwa semua agama itu pada mulanya menganut prinsip yang sama, dan persis karena alasan inilah Alquran "mengajak” kepada titik pertemuan (kalimat sawä) (Qs.3:64).21

Demikian pula dengan Lukman Arake, pada dasarnya setiap agama bertujuan mewujudkan kebaikan dan keselamatan bagi penganut-penganutnya. Maka yang perlu ditumbuhkan pada setiap muslim, khususnya generasi muda Islam, adalah kesediaan untuk bekerja sama dan berinteraksi dengan penganut agama lain dalam mewujudkan kedamaian dan kebaikan bersama, sebagai aplikasi dari seruan Alquran untuk bersatu dalam kalimat sawä.22

Istilah kalimat saw $\bar{a}$, sudah barang tentu dirujukkan pada persamaan kalimat persaksian: annahū là ilāh illa Huwa tersebut. Kalimat ini secara esoteris-substantif merupakan dimensi "sinkronisitas" dari al-Taurāt, al-Injīl dan al-Qur'ān pada tatarannya yang eksistensial, dan inilah titik temu itu. ${ }^{23}$ Pandangan ini setidaknya

\footnotetext{
${ }^{21}$ Budhy Munawar-Rachman, Islam Pluralis Wacana Kesetaraan Kaum Beriman, h.20.

22 Afifuddin, "Pluralisme Keagamaan pada Lembaga Pendidikan Islam Tradisional," h.150.

${ }^{23}$ Konteks eksternal (hadis) dari penjelasan Qs.3:64 dapat dilihat pula dalam sebuah riwayat: Bukhari (4188) dan Muslim (3322).
} 
memecah prasangka ontologis mengenai Allah. Maksudnya annahū apabila dilihat dari sudut pandang Nabi Muhammad sebagai pembicaranya (mutakallim) dan dalam hal representasinya pada Nabi Musa dan Isa maka asybadu.

Dalam konteks inilah setiap buwa (ketiga nabi) yang menegasi dirinya sendiri dengan mengecualikan Huwa yang bukan dirinya maka dalam kesatuannya mengemuka sebagai asyhadu an lā ilāh illa Allāh. Dengan demikian teks-afirmasi tersebut bisa dikatakan sebagai “ujian” (Jawa: ngates). Pembacaan terhadap suatu ayat selaiknya dilakukan dalam bingkai keutuhannya sebagai kesatuan gagasan, sehingga bisa diketahui dalam konteks seperti apa ayat itu dibicarakan. Dalam pengertian inilah (ujian), dan dalam kaitannya dengan syahida Allăh tersebut, di tempat lain (ayat) dinyatakan melalui istilah sibghat Allab (Qs.2:138).24

Pemaparan tersebut setidaknya dapat menjelaskan pandangan Komaruddin bahwa teologi merupakan refleksi kritis dari iman yang keluar sebagai sebuah pertanggungjawaban rasional. Namun karena teologi bersandar pada "logos" atau penalaran, maka sebagai sebuah wacana rasional teologi tidak sanggup menampung dan mengekspresikan misteri dan kedalaman iman mengenai pengalaman seseorang. ${ }^{25}$

Titik masalah dari pandangan teologis tersebut justru terletak pada "prasangka baik"-nya, bahwa setiap orang telah mengantongi iman di dadanya. Ini sesuatu yang kontradiktif dengan spirit “ajakan” (ilā kalimat sawà') yang dibungkus dalam kalimat perintah (amr: qul) itu. Sebab, tidak akan ada ajakan jika setiap dada telah tertanam iman. Maksudnya ajakan itu "ada” karena kenyataan bahwa "yang

${ }^{24}$ Dalam semiotika apa yang disebut sebagai tanda adalah segala sesuatu yang dapat dianggap sebagai pengganti sesuatu yang lain secara signifikan. Sesuatu yang lain itu tidak harus ada atau benarbenar ada di suatu tempat pada saat tanda menggantikannya (sebagaimana kekuasaan negara-polisi tidak selalu harus hadir di setiap titik persimpangan jalan. Rambu-rambu lalu lintas adalah representasi kehadirannya -penulis). Jadi semiotika pada prinsipnya adalah disiplin ilmu yang yang mengkaji segala sesuatu yang dapat digunakan untuk mendustai, mengelabuhi atau mengecoh. Jika sesuatu tidak dapat digunakan untuk mengecoh, berarti ia tidak dapat digunakan untuk mengatakan sesuatu pun. Inilah yang dalam semiotika disebut "teori dusta". Panuti Sudjiman dan Aart Van Zoest, Serba-Serbi Semiotika, Jakarta: Gramedia Pustaka Utama, 1992, h.31-32.

${ }^{25}$ Komaruddin Hidayat dan Muhammad Wahyuni Nafis, Agama Masa Depan, h.123-124. 
diajak" belum atau tidak beriman. Jika yang diajak sudah beriman lantas apa artinya sebuah ajakan?

Persis seperti kalimat là ilāh illā Huwa, bahwa jika ilāh lain yang disembah manusia nyata-nyata "tidak ada" maka bantahan là (ilāh) menjadi kata-kata hampa tak bermakna. Tidak akan ada negasi jika ilāh lain memang tidak ada -apa yang hendak dinegasi? Agar penegasian itu bermakna maka sesuatu yang dinegasi tentu harus ada; atau kalimat negatif (misal, Saya tidak makan nasi) bisa bermakna hanya karena adanya kalimat positif (Saya makan nasi) sebagai kalimat yang diingkari.

Bentuk kesalahpahaman atau prasangka ontologis lain berikutnya mengenai Allah terlihat dalam pandangan, semisal yang diajukan Thoha, bahwa Islam mengakui adanya pluralitas agama, ras dan kultur sebagai kehendak Allah (Qs.11:118) tetapi tidak mengakui pluralisme yang memandang semua agama sama. Mengingat adanya perbedaan fundamental secara teologis di antara agamaagama. Islam adalah agama tauhid yang mengakui Allah sebagai Tuhan, sedangkan Yahudi mengakui tuhan Yahweh sebagai tuhan khusus untuk golongan mereka; Kristen mengimani satu tuhan dalam bingkai Trinitas (Tuhan Bapak, Tuhan Anak dan Ruh Kudus). Sedangkan agama-agama non-semitik seperti Hindu, Majusi, Taoisme dan lainnya beriman kepada banyak Tuhan atau golongan yang sering disebut politeistik. ${ }^{26}$

Pandangan seperti itu memang telah merundungi nalar pesantren baik dari kalangan pluralis maupun partikularis. Sebagai akar dari krisis epistemologis prasangka ontologis yang terdapat pada pernyataan semacam itu setidaknya tercermin dalam ungkapan "kehendak Allah" yang dikaitkan dengan Qs.11:118, dan yang didasarkan pada "perbedaan fundamental secara teologis." Pandangan serupa dinyatakan pula oleh Moqsith, bahwa Tuhanlah yang menghendaki makhlukNya bukan hanya berbeda dalam realitas fisikal, melainkan juga berbedabeda dalam ide, gagasan, keyakinan dan agama sebagaimana disebut dalam

\footnotetext{
26 Dikutip dalam Harda Armayanto, "Problem Pluralisme Agama," h.337.
} 
firmanNya antara lain dalam Qs.11:118. Dari ayat ini sangat jelas bahwa ketunggalan dalam beragama dan berkeyakinan tidaklah dikehendaki Tuhan. ${ }^{27}$

Di kalangan pesantren pandangan senada diungkapkan oleh Fathurrahman, seorang pimpinan Pondok Pesantren al-Junaediyyah Biru Kabupaten Bone. Ia menyepakati bahwa kemajemukan dan keberagaman merupakan sunnatullah yang ditetapkan Allah pada segenap makhlukNya. Tidak ada satu pun makhluk yang sama persis dengan lainnya. Manusia diciptakan dengan perbedaan-perbedaan antara satu sama lain. Akidah Islam menegaskan bahwa hanya Allah satu-satunya yang Esa, tunggal dan tidak majemuk. Kemajemukan makhluk pada dasamya menunjukkan ke-Esa-an al-Khaliq. ${ }^{28}$

Demikian pula yang dikemukakan Lukman Arake, Wakil Direktur Pondok Pesantren al-Ikhlas Ujung Bone. Menurutnya, perbedaan antara laki-laki dan perempuan, perbedaan ras, etnis, suku, bahasa dan agama (kepercayaan) merupakan kenyataan yang tidak dapat dipungkiri bahwa pluralitas merupakan sifat dasar kehidupan di alam ini. Menyatukan dan menyeragamkan keseluruhan perbedaan-perbedaan itu dalam satu bahasa atau agama misalnya, pada hakikatnya bertentangan dengan sunnatullah (hukum alam) dan kemanusiaan. ${ }^{29}$

Khalilur Rahman menyatakan bahwa pandangan para pimpinan dan tenaga pengajar di Pondok Pesantren Tebuireng, Jombang dan Nurul Jadid, Paiton Probolinggo (Jawa Timur), cenderung pada pandang inklusif-pluralis. Mereka menganggap bahwa perbedaan sebagai takdir, sunnatullah, dan memang harus ada sebagai sebuah keniscayaan. Seluruh perbedaan memiliki nilai-nilai positif banyak, yang apabila dipertemukan, akan menjadi kekuatan tersendiri untuk membangun harmoni, perdamaian, dan stabilitas kehidupan sosial dalam perbedaan. ${ }^{30}$

Akan tetapi realitasnya adalah dengan adanya ajakan (ilä kalimat saw')') maka hal itu justru membuktikan bahwa sebagai suatu fakta pluralitas agama bukan

27 Abdul Moqsith Ghazali, Argumen Pluralisme Agama, h.xvi.

${ }^{28}$ Lihat Afifuddin, "Pluralisme Keagamaan pada Lembaga Pendidikan Islam Tradisional (Studi Sosiologis Filosofis tentang Pluralisme pada Pondok Pesantren di Kabupaten Bone)", h.149.

29 Afifuddin, "Pluralisme..."

${ }^{30}$ Khalilur Rahman, "Strategi Pengembangan Nilai Toleransi dan Pluralisme dalam Pendidikan Pesantren, Hikmah, Vol. XII, No. 1, 2016, h.123. 
merupakan realitas-kehendak Allah, melainkan realitas-perwujudan dari penentangan terhadap āyät Allāh (perintah). Logikanya tidak berubah: tidak ada perintah-ajakan jika memang penentangan itu tidak ada (manifested). Di sinilah letak relevansinya dengan al-dìn sebagai konsep tentang waktu: yaum (al-din) yang lā raiba fǐh, ungkapan yang telah mengalami ma'rifat-isasi sebagai al-yaum (Qs.5:3, Qs.1:4).

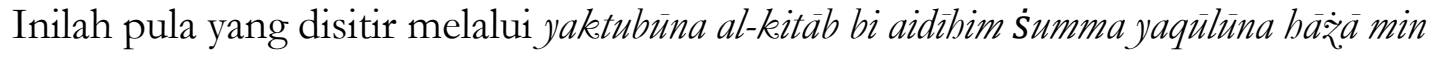
indi Allāh (Qs.2:79 yang serupa tapi tak sama atau analog dengan Qs.10:18).

Kesalahpahaman di atas semakin jelas ketika mencermati Qs.49:13 yang secara faktual tidak menyebut aspek keagamaan di dalamnya. Bila pluralitas dinisbatkan pada selain agama yang terkait dengan realitas empiris sebagai pengetahuan inderawi tentu bisa dimengerti. Akan tetapi bila menyangkut agama, sekalipun dalam pengertian yang formal, maka terlihat dengan jelas bahwa ayat itu tidak menyinggung apapun tentang hal itu. Inilah salah satu bentuk ketidakjelasan dalam melakukan pembedaan antara realitas dan fakta, dan yang memicu timbulnya prasangka-prasangka.

Jadi pernyataan pluralitas agama sebagai kehendak Allah merupakan cara pembacaan yang tidak kontekstual, tidak proporsional, tidak bi al-qisț. Secara faktual (sebagai yang tampak) seolah-olah Tuhan memang menghendaki keragaman dan faktanya memang ada beragam institusi agama -dikatakan sebagai perbedaan fundamental teologis. Tetapi secara realitas (sebagai yang tak terlihat, termasuk ayatnya Qs.3:64 atau Qs.2:79) tentu tidak demikian. Adanya perintahajakan itu adalah sebagai buktinya. Barangkali masalah seperti inilah yang dipikirankan Frued mengenai persaksian iman sebagai ilusi, dan segala sesuatu tampak "tepat seperti apa yang kita inginkan".

Atas dasar sedikitnya dua bentuk prasangka ontologis di atas, dan itulah pula alasannya mengapa dalam ayat berikutnya (Qs.3:20) dipertanyakan soal ke-al-islamannya: aaslamtum?31 Suatu pertanyaan retorik-konfirmatif yang menghendaki

31 Secara analogis dimensi ontologis dari al-islam sebagai sikap pasrah atau tunduk (sikap keagamaan) dalam kaitannya dengan al-din bisa diilustrasi saat kita berkendara di jalan raya (safar, Qs.2:185). Sesampai di simpang jalan kita menjumpai lampu (rambu lalu lintas) menyala kuning. Ini berarti "peringatan-perintah" untuk lebih berhati-hati atau mulai mengarahkan kaki pada pedal rim. Pada saat lampu menyala merah berarti ada "perintah" untuk menginjak rim (berhenti), ekuivalen 
umpan balik atas peringatan: wa man yak.fur... (Qs.3:19) kendati sebenarnya jawaban itu tidak diperlukan. Pertanyaan itu dimaksudkan untuk membuat pemetaan atau pembedaan (Qs.14:27) dari man (siapa saja) yang berasal dari -dan tidak terbatas pada- tiga institusi agama saja (Yahudi, Nasrani dan Islam) yang melakukan pengingkaran dan yang tidak. Pada titik inilah "silang pendapat" (setelah adanya al-ilm yang memberi penjelasan perihal baghyan bainahum, Qs.3:19) membelah setiap institusi agama menjadi dua golongan (Qs.3:13), dan pada saatnya tiga golongan (Qs.56:7). Inilah setidaknya dimensi proporsionalitas yang telah disinggung di awal pembicaraan (Qs.25:2).

Kesadaran agama universal - dimana Islam adalah salah satu partikularnyatelah menghasilkan pandangan bercorak antroposentris, bahwa pada mulanya umat manusia adalah tunggal, karena pada mulanya mereka berpegang pada "Kebenaran Tunggal" itu, yaitu tauhid. Tetapi kemudian manusia berselisih paham, justru setelah penjelasan tentang Kebenaran Tunggal itu datang, ${ }^{32}$ (Qs.21:92-93).

\section{Jalan Buntu Pencarian Titik Temu}

Ragam pandangan tentang pluralisme agama merupakan cermin dari adanya perbedaan dalam menanggapi relasi antara kebenaran tunggal dan dimensi faktual tentang yang plural itu sendiri: pluralitas agama. Relasi antara realitas dan fakta. Di

dengan "larangan" untuk tancap gas. Dalam situasi seperti ini kita dihadapkan pada dua pilihan yang bertentangan: berhenti versus terus meluncur. Karenanya kemudian pasrah bisa diartikan dalam dua situasi: pasrah sebagai berhenti, atau pasrah dalam arti menerima hukuman-tilang sebagai wujud "kemarahan" polisi (representasi penguasa) atau ditegakkannya peraturan-hukum. Terlebih jika pelanggaran menyebabkan kecelakaan yang menyebabkan kebutaan, misalnya, maka kita terpaksa harus pasrah menjalani hidup penuh penyesalan (tidak lagi bisa melihat indahnya warna) gara-gara urusan sepele: menabrak lampu merah. Menabrak lampu merah artinya menganggap lampu merah "tidak ada" atau yang dipikirkan hanya lampu hijau. Tidak menyadari bahwa warna hijau adalah kombinasi dari warna biru dan kuning. Biru melambangkan warna langit-ketinggian (otoritas perintah-peraturan, titah langit) dan warna kuning adalah simbol peringatan-waspada. Jika kuning dianggap remeh dan merah diabaikan, terlebih itu adalah tanda akan datangnya perintah berhenti, maka perintah tilang (hukuman) pun datang dan yang terjadi adalah penyesalan (mending seratus ribu buat ngopi sama teman).

Kaidah fikih: al-aṣl fì syurūt fí al-mu'ämalāt al-hill wa al-ibähah illā bi dalì-in adalah salah satu kaidah yang sering disalahpahami. Tidak jarang pembacaan kita terhenti pada ibähahnya dengan mengabaikan aspek illa-nya, sementara dimensi terpenting dari kaidah ini -seperti halnya dalam masalah akidah- justru terletak pada aspek illä-nya itu agar tidak bernasib sama seperti Nietzsche. Lupa bahwa di dalam hijau (kebolehan) ada biru (titah langit) dan kuning (inti titah: peringatan).

32 Budhy Munawar-Rachman, Islam Pluralis Wacana Kesetaraan Kaum Beriman, h.20. 
kalangan pluralis pesantren tidak ditemukan perbedaan yang tajam menyangkut adanya kebenaran pada setiap agama. Istilah seperti the common vision sebagai visi bersama agama-agama, atau the world religion sebagai kesatuan agama-agama tidak jarang menghiasi gagasan dasarnya tentang millah Ibrāhim.

Dalam hal ini kalangan pluralis menaruh perhatian pada pentingnya menciptakan suasana dialogis, dimana gagasan tentang toleransi menemu muaranya -adalah gagasan yang sulit ditampik oleh partikularis. Pemikiran di seputar dialog agama-agama dan toleransi beragama tidak henti-hentinya bermunculan, baik itu menyangkut masalah metode, formulasi hingga isu-isunya yang strategis. Dalam pandangan Elmirzana sedikitnya terkait dengan tiga bidikan:

Pertama, membangkitkan semangat kerja sama antar agama dalam bayangbayang ketiadaan perdamaian; kedua, menciptakan kesadaran dalam kerangka akademik tentang ketidakterbatasan hakikat yang-ghaib, de-absolutisasi kebenaran, menjalin mutualisme dan saling melengkapi; dan yang ketiga, menempatkan dialog sebagai resolusi konflik. ${ }^{33}$

Dalam pernyataan ini sebuah ungkapan "de-absolutisasi kebenaran” adalah bentuk krisis yang lain. Gagasan ini dapat menggerogoti apa yang dipersepsi sebagai là raiba fìh yang berujung pada ambiguitas. Seperti sebelumnya, gagasan ini bisa menjauhkan pengertian yang sudah ditentukan pada setiap kata berartikel-al dalam Alquran. Dalam kerangka al-ilm ungkapan tersebut dapat diidentikkan dengan de-ma'rifat-isasi terhadap "kepastian" makna yang telah "ditunjuknya".

Sebuah harapan yang cukup beralasan bahwa setiap agama bisa menuju titik temu pada millah Ibrähìm. Tetapi kegagalan dalam memberi rumusan substantif yang jelas mengenai itu justru memberitahu gagasan toleransi menemu situasi jalan buntu dan mentoknya dialog pada tatarannya yang substantif. Situasi ini menjelaskan bahwa apa yang disebut dialog adalah tidak lebih dari duduk bersama dan berbicara dalam satu meja yang sama yang tujuannya adalah meredam konflik atau meminimalisasi potensi kemunculannya. Kontradiktif dengan persepsi bahwa sejarah adalah sejarah konflik -ketiadaan perdamaian. Bahkan sejak pada mulanya

33 Syafa'atun Elmirzana, "Pluralisme, konflik dan Dialog" dalam Esensia: Jurnal Ilmu-ilmu Ushuluddin, Vol.2, No.1, Januari 2001, h.45-46. 
sejarah bahwa konflik merupakan sesuatu yang niscaya adanya, ini jika dilacak dari konflik yang terjadi antara kedua putra Adam: Qabil dan Habil.

Gagasan tentang titik temu (the common vision atau the world religion) memang cukup relevan akan tetapi yang terjadi justru pembelokan orientasi atau terdampar pada toleransi. Ini berarti toleransi bisa dikatakan sebagai suatu "pelarian" atau ekspresi dari kekecewaan dan kelelahan dalam menghadapi kebuntuan akan pencarian titik temu. Jika asumsi ini bisa diterima maka hal ini tak ubahnya seperti mendekatkan dua kutub magnet yang sama (kesamaan pengakuan di bawah satu payung millah Ibrähim) dan karenanya tidak pernah bisa ditemukan di dalam toleransi. Sedangkan muara dari itu ialah meregangnya kutub-kutub lainnya yang menampil dalam bentuk penolakan dan gugatan. Dengan kata lain titik temu itu bukan terletak pada toleransi, kendati dialog tetap memegang peranan kunci.

Di sisi lain, Arifin Ismail, dalam Sikap Pesantren dalam Menghadapi Paham Pluralisme Agama, memaparkan bahwa salah satu agenda pesantren adalah memberi penjelasan mengenai kedudukan agama Islam di tengah pluralitas agama sehingga toleransi agama hanya berkisar kepada akhlak dan muamalah, dan tidak masuk ke dalam ranah akidah dan syariat. ${ }^{34} \mathrm{Hal}$ ini memberitahu perihal kegamangan nalar pesantren (adanya double bind) dalam mengartikulasi millah Ibrähim di lingkungannya sendiri sebagai ketertutupan teologis di tengah dibukanya pintu toleransi di ranah kehidupan sosial. Bisakah sikap yang demikian ini dikatakan sebagai terjebak dalam pusaran sekularisme?

\section{Penutup}

Toleransi merupakan ide yang sudah tidak asing lagi bagi nalar pesantren. Tetapi toleransi bukan merupakan jalan keluar bagi pencarian titik temu dan dialog agama-agama, juga bukan solusi bagi perlindungan teologis dari "keterancaman" akidah lain. Sebab toleransi tidak lebih dari sebuah gambaran tentang situasi kelelahan dan kepenatan di tengah-tengah kebuntuan. Tetapi toleransi juga bukan merupakan kesalahan; ruang lingkup pembahasan ini tidak

${ }^{34}$ Muhammad Arifin Ismail, "Sikap Pesantren dalam Menghadapi Paham Pluralisme Agama," dalam Toleransi, Vol. 5 No. 2 Juli - Desember 2013, h.123. 
berbicara tentang apa yang-salah dan yang-benar melainkan tentang sesuatu yang lebih memberi kepastian tentang yang dianggap "benar" dengan menegasi aspek ketidak-pastiannya. Adalah proses singularisasi -dan bukan partikularisasi- atas yang plural-universal (ma'rifat-isasi dari yang nakirab); atau bisa pula dikatakan "yang bukan-bukan"-isasi terhadap pertentangan antara apa yang dipandang sebagai- yang-universal dan yang-partikular, jadi sintesa terbalik.

\section{Daftar Pustaka}

Abdullah, Amin, "Dialog Peradaban Menghadapi Era-Postmodernisme, Sebuah Tinjauan Filosofis-Religius," al-Jami'ah, No. 53 (1993).

Abdullah, Amin, "Fiqh dan Kalam Sosial Era Kontemporer, Perjumpaan Ulum aldin dan Sains Modern Menuju Fresh Ijtihad," dalam Tutik Nurul Janah (ed.), Metode Fiqh Sosial: Dari Qouli Menuju Manhaji, Pati: Fiqh Sosial Institue, 2015.

Abdurrahman, Muslim, Islam Transformatif, Jakarta: Pustaka Firdaus, 1997.

Abercrombie, Nicholas; Stephen Hill, Bryan S. Turner, Kamus Sosiologi, Yogyakarta: Pustaka Pelajar, 2010.

Afifuddin, "Pluralisme Keagamaan pada Lembaga Pendidikan Islam Tradisional (Studi Sosiologis Filosofis tentang Pluralisme pada Pondok Pesantren di Kabupaten Bone)" Jurnal Al-Qalam, 18, no. 1 (2012).

Al-Attas, Muhammad al-Naquib, Islam dan Sekularisme, Bandung: Penerbit Pustaka, 1981.

Anwar, Rosihon; Dadang Darmawan dan Cucu Setiawan, "Kajian Kitab Tafsir dalam Jaringan Pesantren Di Jawa Barat, Wawasan: Jurnal Ilmiah Agama dan Sosial Budaya, 1, no.1 (2016).

Arifin, Syamsul, "Konstruksi Wacana Pluralisme Agama di Indonesia," Humanity, V, no. 1 (2009).

Arifin, Zainal, dan Yu'timaalahuyatazaka, "Persepsi Santri Dan Kiai Terhadap Pluralisme Agama di Pendidikan Ulama Tarjih Muhammadiyah (Putm) dan Aswaja Nusantara Yogyakarta," Al-Tabrir: Jurnal Pemikiran Islam,. 17, No. 1 (2017).

Armayanto, Harda, "Problem Pluralisme Agama," Jurnal Tsaqafah, 10, No. 2, (2014).

Bakker, Anton, dan Achmad Charris Zubair, Metodologi Penelitian Filsafat, Yogyakarta: Penerbit Kanisius, 1994. 
Elmirzana, Syafa'atun, "Pluralisme, konflik dan Dialog" Esensia: Jurnal Ilmu-ilmu Ushuluddin, 2, No.1, (2001).

Fata, Ahmad Khoirul, dan Fauzan, "Kritik "INSISTS" terhadap Gagasan Pluralisme Agama," Kalam, 11, no. 1, (2017).

Freud, Sigmund, Musa dan Monoteisme, Yogyakarta: Penerbit Jendela, 2003.

Geertz, Clifford, Kebudayaan dan Agama, Yogyakarta: Penerbit Kanisius, 1992.

Ghazali, Abdul Moqsith, Argumen Pluralisme Agama, Depok: Kata Kita, 2009.

Hadi, P. Hardono, Epistemologi, Filsafat Pengetahuan, Yogyakarta: Penerbit Kanisius, 1994.

Hidayat, Komaruddin; dan Muhammad Wahyuni Nafis, Agama Masa Depan Perspektif Filsafat Perennial, Jakarta: Penerbit Paramadina, 1995.

Ismail, Muhammad Arifin, "Sikap Pesantren dalam Menghadapi Paham Pluralisme Agama," Toleransi, 5, No. 2 (2013).

Izudin, Ahmad, "Paradigma Integrasi-Interkoneksi: Analisis Epistemologis Pemikiran Keislaman M. Amin Abdullah," Islamic Review: Jurnal Riset dan Kajian Keislaman, IV, No.1, (2015).

Misrawi, Zuhairi, Al-Qur'an Kitab Toleransi: Inklusivisme, Pluralisme, dan Multikulturalisme, Jakarta: Fitrah, 2007.

Munawar-Rachman, Budhy, "Perspektif Global Islam dan Pluralisme," Jurnal Ushuluddin, 1, No. 3, (2012).

Munawar-Rachman, Budhy, Islam Pluralis Wacana Kesetaraan Kaum Beriman, Jakarta: Raja Grafindo Persada, 2004.

Nafi'a, Ilman, "Fatwa Pluralisme dan Pluralitas Agama MUI (Majlis Ulama Indonesia) dalam Perspektif Tokoh Islam Cirebon," Holistik, 14, No. 1, (2013).

Nasr, Seyyed Hossein, Islam antara Cita dan Fakta, Yogyakarta: Pusaka, 2001.

Rahman, Khalilur, "Strategi Pengembangan Nilai Toleransi dan Pluralisme dalam Pendidikan Pesantren”, Hikmah, XII, No. 1, (2016).

Robenson, Dave, Nietzsche dan Postmodernisme, Yogyakarta: Penerbit Jendela, 2002.

Scharfenberg, Joachim, Sigmund Freud, Pemikirann dan Kritik. Agama, Yogyakarta: AK Group, 2003.

Schuon, Frithjof, Islam dan Filsafat Perenial, Bandung: Penerbit Mizan, 1993.

Shihab, Alwi, Islam Inklusif: Menuju Sikap Terbuka dalam Beragama, Bandung: Penerbit Mizan, 1999.

Sobur, Alex, Kamus Psikologi, Bandung: Pustaka Setia, 2016.

Sudjiman, Panuti, dan Aart Van Zoest, Serba-Serbi Semiotika, Jakarta: Gramedia Pustaka Utama, 1992. 
Krisis Epistemologis Pesantren ...

Sumbulah, Umi, dan Nurjanah, Pluralisme Agama: Makna dan Lokalitas Pola Kerukunan Umat Beragama, Malang: UIN-Maliki Press, 2013.

Suseno, Franz Magnis, 13 Tokoh Etika, Yogyakarta: Penerbit Kanisius, 1997.

Syamsuddin, Mukhtasar, "Metode Refleksi Fenomenologis Maurice MerleauPonty," dalam Rezza A.A. Wattimena, (ed.) Metodologi Penelitian Filsafat, Yogyakarta: Penerbit Kanisius, 2011.

Tamam, Badrut, Pesantren, Nalar dan Tradisi, Geliat Santri Menghadapi ISIS, Terorisme dan Transnasionalisme Islam, Yogyakarta: Pustaka Pelajar, 2015.

Thoha, Anis Malik, Tren Pluralisme Agama: Tinjauan Kritis, Depok: Perspektif, 2005

Yazdi, Mehdi Ha’iri, Ilmu Hudhuri, Prinsip-prinsip Epistemologi dalam Filsafat Islam, Bandung: Penerbit Mizan, 1994. 